\title{
Study Regarding the Improvement of Bottling Process for Spring Waters, through the Implementation of the Occupational Health and Food Safety Requirements
}

\author{
Ioana Glevitzky ${ }^{1, *}$, Adina Sârb ${ }^{1}$ and Maria Popa ${ }^{2}$ \\ 1 Doctoral School, Faculty of Engineering, "Lucian Blaga” University of Sibiu, 550024 Sibiu, Romania; \\ sarb.adina92@yahoo.com \\ 2 Faculty of Economic Sciences, “1 Decembrie 1918” University of Alba Iulia, 510009 Alba Iulia, Romania; \\ mpopa@uab.ro \\ * Correspondence: ioana_glevitzky@yahoo.com; Tel.: +40-0358-11-2534
}

Received: 30 December 2018; Accepted: 6 May 2019; Published: 22 May 2019

\begin{abstract}
The design, development and deployment, alongside with preventive maintenance of equipment helps with controlling safety issues in water bottling processes. However, these aspects are not-enough to prevent accidents; they must be closely related to the implementation of quality, occupational health and safety, and food security standards. The approach presented in this paper was to show a summary of the assessment of the risks of injury and professional illness for all within the organization according to the ISO 45001:2018 standard. Also, a statistical analysis was performed to evaluate the occurrence of defects in different equipment in the technological process. The paper highlights the safety parameters of the spring water "Roua Apusenilor" namely the: organoleptic, physic-chemical and microbiological ones, according to the European legislation. A hazard analysis and critical control points (HACCP) generic model was developed for this process. In this case study, the analysis and assessment of hazards that may occur during processing was implemented for still water bottling stages, as was an identification of the critical control points, which include filtration and ozone water treatment. The HACCP principles, included in the ISO 22000:2018 standard, were applied in order to improve the food safety and security, to reduce the risks resulting from the consumption of "Roua Apusenilor" spring water and, also, for increasing customer confidence. The obtained results significantly relied upon the situation found in the industrial company used as a benchmark for the research. The analysis revealed that, considered safety standards OHSAS (ISO 45001) and HACCP (ISO 22000) share the same goal of safety production for safe food products.
\end{abstract}

Keywords: still water; maintenance; occupational health and safety; food safety; risk assessment

\section{Introduction}

In the United Kingdom food industry, food safety issues are being examined and corroborated with regulations in the field of occupational health and safety, because they have been the key testing grounds for developing risk-based regulation [1]. Also, there are studies that show that hazard analysis and critical control points (HACCP) and occupational safety and health (OHS) can help improve each other in the catering sector [2]. The health and safety of the products and employees in the bottled water industry should be prioritized in the wake of increasing risks in sensitive service industries [3].

Underground waters are an important resource, given that unlike surface waters, they are usually less polluted or even unpolluted. Therefore, underground waters may be made potable using minimal measures, sometimes using only disinfection, or without any treatment [4]. A water quality assessment is made by the measuring of certain parameters (physical, chemical and microbiological) whose limits are defined using legitimate standards [5]. The drinking water quality is set by Law 
no. 311/2004 which completes the Law no. 458/2002 (in Romania) [6], harmonized with European Union legislation-Council Directive 98/83/EC [7]. Drinking water must be health providing, clean, without microorganisms, parasites or substances which, by number or concentration, can be a potential hazard for human and animal consumption [8].

Ensuring water in the required quantity and at the highest quality for optimal living conditions is a very important problem for each nation and it represents one of the food security and safety objectives. The General Assembly of the United Nations announced the period 2005-2015 to be the International Decade of "Water for Life" in order to understand and to react in a certain way or take a specific action in response to this message [9]. Therefore, drinking water is an essential element for ensuring public health and quality of life. Currently, drinking water sources-rivers, lakes and ground water-are threatened by different types of contaminants [10]. In the food industry of bottling spring water, equipment always plays an important role. The Directive 2006/42/EC provides integrated essential safety and health requirements. Its aims include the free market circulation of machinery and the protection of the workers and consumers using such machinery. It defines the essential health and safety requirements for general application, including regarding foodstuffs machinery. They must be designed and constructed in such a way as to avoid any risk of infection, sickness or contagion [11].

The collateral cost of equipment failures cannot be afforded to a rigorously programmed production, respectively to the lost time needed to remedy the deficiency. The impact that breakdowns have on process and the frequency with which they occur are key factors in managing equipment or ensuring proper maintenance. Therefore, "prevention is better than a cure" is the principle that should be follow in equipment management and maintenance. The maintenance actions taken before failure are more cost-effective, less disruptive, and are easier to manage than repair actions taken after the machine has broken down and defined both the time and place for the urgently required repair action [12].

In this context, the motivation of the present study has increased due to the interest shown in relation to the safety of bottled waters, both from a product perspective as well as in analysis and assessment of the risks at all stages of the technological process. At the same time, the purpose of this research is to assess the current situation of the water safety of "Roua Apusenilor" by applying modern tools for occupational health and safety, as well as for food safety-the ISO 45001 and ISO 22000 standards $[13,14]$ in order to ensure that the water consumed by the inhabitants of the region is safe and conforms to available quality standards.

In the context of the issues described above, until now OHSAS 18001 [15] was a model for the organizations that strive for better control regarding occupational hazards, presenting legal requirements and other requirements applicable to environmental and occupational health and safety issues. Therefore, the standard was designed in order to complete the quality-ISO 9001 and environment-ISO 14001 management systems [16,17]. It was based on explicit requirements for an effective management of occupational hazards and the development of a culture of prevention among employees. Starting in 2018, the ISO 45001 standard replaced OHSAS 18001, thus ISO recognition will increase credibility and will determine its application on a larger scale. The implementation of an occupational health and safety management system provides a work system that helps in reducing the number of occupational accidents, illnesses and injuries.

At the same time, the production, processing, packaging, storage, distribution and selling of food requires uniformity given the food safety perspective. Thus, the ISO 22000 standard is a useful answer to these challenges. The standard sets the requirements and defines what an organization needs to do in order to demonstrate its ability to control food safety hazards "from farm to fork" by providing hygiene practices and traceability at every step of the food chain. The development of a food safety management system considers the potential risks and threats to the organization as well as the impact on business processes [18]. The HACCP system is recognized worldwide as a systematic and preventive approach to controlling biological, chemical and physical hazards by anticipating and preventing inspections and analyses of the finished product [19]. 
The HACCP system is a food safety management system that uses the approach of identification, evaluation, and control of the critical points in food and drink production, and the framework of its concept consists of seven principles [20]: Principle 1: Conduct a hazard analysis; Principle 2: Determine the critical control points (CCPs); Principle 3: Establish critical limits; Principle 4: Establish monitoring procedures; Principle 5: Establish corrective actions; Principle 6: Establish verification procedures; Principle 7: Establish record-keeping and documentation procedures.

The present paper aims to find methods of improving the bottling process of spring waters through the implementation of the requirements of both ISO 45001 standard regarding the occupational health and safety, and of ISO 22000 standard related to the management system for quality and safety. This should be acquired both through testing the quality of drinking bottled water, as well as a requirement of the quality management system implemented in Monopolis SA Company, near Câmpeni Town Centre. This company is the only production unit in the county that now works in the field of bottling spring waters since 2005. It is located in the Apuseni Mountains, Alba County, Transylvania, Romania.

\section{Methodology}

The first stage of the study was to analyze data related to the implementation of environmental and occupational health and safety requirements for all workplaces in Monopolis SA Company. The study helped understand the process of identifying, accessing and determining how to apply and assess compliance with legal requirements and other requirements applicable to environmental and occupational health and safety aspects.

At the same time, the design and deployment of phases in the technological process of water bottling, together with the implementation of an occupational health and safety standard does not constitute enough control of safety issues that may arise in the production processes. In this way, periodically, it is necessary, to carry out a statistical study of the problems that occur in order to establish the periodicity in maintaining maintenance of the machinery and equipment. Thus, in the second stage of the research, a statistical analysis was performed to evaluate the incidence of occurrence of defects at various equipment from the technological process of capture, transport and bottling of spring water. The study aimed to demonstrate whether there is an intercorrelation between these defects, whether it is necessary to increase the periodicity of maintenance on different equipment in the production process.

The third stage of the research is a qualitative investigation of "Roua Apusenilor" spring water safety at source and the justification of the necessity to implement a management system for quality and food safety according to the ISO 22000. This can provide control over the technological process, in all stages, through the evaluation of the three possible risks: physical, chemical and biological. In this sense, a generic HACCP model was developed.

In the context of the current problems that increase the risk of water scarcity, the research carried out outlines the current situation with regards to drinking water safety at the level of Alba County, Romania. If public drinking water systems use only surface waters (lakes, rivers), groundwater (spring, wells, drilling) will be an alternative, that will be less and less explored and exploited, even if it is a natural and free source.

The Câmpeni area is situated in a depression, surrounded by mountains [21]. The bottling factory supplies both local food stores (approx. 8000 inhabitants), but also has national coverage. The water produced is distributed in two supermarket chains across the country.

For qualitative and safety assessment of spring water, one sample was collected and analysed from the spring "Lucia Cave" (water source for the factory), in May 2018. The assessment was performed in the absence of atmospheric precipitation 7 days before, which could influence the results of laboratory analyses. The sample was collected from the source: Sohodol village, Alba county, Romania. After capture, the spring water was transported through a polyethylene pipe $(2880 \mathrm{~m})$ to the 
bottling unit belonging to Monopolis SA Company, in the Town of Câmpeni. The registered trademark of the product is "Roua Apusenilor".

Organoleptic, physico-chemical and microbiological analyses were performed according to the working standards specific to each parameter.

\section{Results}

\subsection{Occupational Health and Safety}

The objective of implementing a system according to the ISO 45001 ensures that all personnel within the organization are aware of all legal provisions and requirements applicable in the field of environmental and occupational health and safety. At the same time, by assessing the risks of injury and professional illness, it is intended to comply with the legal requirements to operate in a safe environment.

Tables 1-4 provide a synthesis of the assessment of the risks of injury and occupational disease for all workplaces within the organization through all components of the work system and using the risk assessment grid-a combination of the severity of the consequences and the probability of their occurrence [22].

Table 1. Analysis and evaluation of the risks of injury and occupational disease related to the production equipment factors.

\begin{tabular}{|c|c|c|c|c|c|c|}
\hline $\begin{array}{l}\text { Identified } \\
\text { Risk Factors }\end{array}$ & $\begin{array}{c}\text { The Concrete Form of } \\
\text { Manifestation of Risk Factors } \\
\text { (Description, Parameters) }\end{array}$ & $\begin{array}{l}\text { Causes of Risk } \\
\text { Factors }\end{array}$ & $\begin{array}{c}\text { Maximum } \\
\text { Predictable } \\
\text { Consequence }\end{array}$ & $S^{1}$ & $\mathbf{P}^{2}$ & $\begin{array}{l}\text { Risk } \\
\text { Level }\end{array}$ \\
\hline \multirow{3}{*}{$\begin{array}{l}\text { Mechanical } \\
\text { risk factors }\end{array}$} & $\begin{array}{l}\text { Catching or hitting the } \\
\text { constructive elements of the } \\
\text { equipment }\end{array}$ & $\begin{array}{l}\text { Inadequate signs and } \\
\text { illumination in the }\end{array}$ & 3-45 days & 2 & 2 & 2 \\
\hline & $\begin{array}{l}\text { Clamping, crushing or } \\
\text { knocking by stacked } \\
\text { improperly products }\end{array}$ & $\begin{array}{l}\text { dangerous area } \\
\text { Inadequate training } \\
\text { Inadequate cleaning }\end{array}$ & DEATH & 7 & 2 & 4 \\
\hline & $\begin{array}{l}\text { Free fall in the gravitational } \\
\text { effect of tools, parts handled or } \\
\text { transported }\end{array}$ & & 4-180 days & 3 & 3 & 3 \\
\hline $\begin{array}{l}\text { Thermal risk } \\
\text { factors }\end{array}$ & $\begin{array}{l}\text { Exposure to open fire due to } \\
\text { fire production }\end{array}$ & Inadequate training & DEATH & 7 & 2 & 4 \\
\hline $\begin{array}{l}\text { Electrical } \\
\text { risk factors }\end{array}$ & Electrocutation & Inadequate training & DEATH & 7 & 1 & 3 \\
\hline $\begin{array}{l}\text { Biological } \\
\text { risk factors }\end{array}$ & $\begin{array}{l}\text { Aggression within the } \\
\text { organization }\end{array}$ & Inadequate training & 45-180 days & 3 & 3 & 3 \\
\hline
\end{tabular}

Table 2. Analysis and evaluation of the risks of injury and occupational disease related to the factors of the working environment.

\begin{tabular}{|c|c|c|c|c|c|c|}
\hline $\begin{array}{c}\text { Identified } \\
\text { Risk Factors }\end{array}$ & $\begin{array}{l}\text { The Concrete Form of } \\
\text { Manifestation of Risk Factors } \\
\text { (Description, Parameters) }\end{array}$ & $\begin{array}{c}\text { Causes of } \\
\text { Risk Factors }\end{array}$ & $\begin{array}{l}\text { Maximum } \\
\text { Predictable } \\
\text { Consequence }\end{array}$ & $S^{1}$ & $\mathbf{P}^{2}$ & $\begin{array}{c}\text { Risk } \\
\text { Level }\end{array}$ \\
\hline $\begin{array}{l}\text { Physical risk } \\
\text { factors }\end{array}$ & Air currents & $\begin{array}{l}\text { Inadequate } \\
\text { training }\end{array}$ & 3-45 days & 2 & 4 & 2 \\
\hline \multirow{2}{*}{$\begin{array}{l}\text { Chemical } \\
\text { risk factors }\end{array}$} & Ozone exposure & Inadequate & 3-45 days & 2 & 2 & 2 \\
\hline & Caustic washing solutions & cleaning & 3-45 days & 2 & 4 & 2 \\
\hline
\end{tabular}

${ }^{1} \mathrm{~S}$-Severity; ${ }^{2} \mathrm{P}$-Probability. 
Table 3. Analysis and evaluation of the risks of injury and occupational disease related to the factors of own work load.

\begin{tabular}{|c|c|c|c|c|c|c|}
\hline $\begin{array}{l}\text { Identified } \\
\text { Risk Factors }\end{array}$ & $\begin{array}{l}\text { The Concrete Form of } \\
\text { Manifestation of Risk Factors } \\
\text { (Description, Parameters) }\end{array}$ & $\begin{array}{l}\text { Causes of } \\
\text { Risk Factors }\end{array}$ & $\begin{array}{l}\text { Maximum } \\
\text { Predictable } \\
\text { Consequence }\end{array}$ & $\mathrm{S}^{1}$ & $\mathbf{P}^{2}$ & $\begin{array}{r}\text { Risk } \\
\text { Level }\end{array}$ \\
\hline \multirow{3}{*}{$\begin{array}{l}\text { Inadequate } \\
\text { content }\end{array}$} & $\begin{array}{l}\text { Storage of materials on the access } \\
\text { ways }\end{array}$ & \multirow{3}{*}{$\begin{array}{l}\text { Inadequate } \\
\text { training }\end{array}$} & 45-180 days & 3 & 3 & 3 \\
\hline & $\begin{array}{l}\text { Performing operations for which } \\
\text { they have not been trained }\end{array}$ & & DEATH & 7 & 1 & 3 \\
\hline & $\begin{array}{l}\text { Noncompliance with occupational } \\
\text { safety and health provisions } \\
\text { regarding the exposure to danger }\end{array}$ & & 45-180 days & 3 & 3 & 3 \\
\hline \multirow{3}{*}{$\begin{array}{l}\text { Physical } \\
\text { overload } \\
\text { Psychological } \\
\text { overload }\end{array}$} & Dynamic effort, atypical work cycle & \multirow{3}{*}{$\begin{array}{l}\text { Inadequate } \\
\text { training }\end{array}$} & 3-45 days & 2 & 2 & 2 \\
\hline & Difficult decisions in a short time & & 3-45 days & 2 & 3 & 2 \\
\hline & $\begin{array}{l}\text { Pressure from the top management } \\
\text { of the organization }\end{array}$ & & 3-45 days & 2 & 3 & 2 \\
\hline
\end{tabular}

${ }^{1}$ S-Severity; ${ }^{2}$ P-Probability.

Table 4. Analysis and evaluation of the risks of injury and occupational disease related to factors of performer.

\begin{tabular}{|c|c|c|c|c|c|c|}
\hline $\begin{array}{l}\text { Identified } \\
\text { Risk Factors }\end{array}$ & $\begin{array}{c}\text { The Concrete Form of } \\
\text { Manifestation of Risk Factors } \\
\text { (Description, Parameters) }\end{array}$ & $\begin{array}{c}\text { Causes of } \\
\text { Risk Factors }\end{array}$ & $\begin{array}{l}\text { Maximum } \\
\text { Predictable } \\
\text { Consequence }\end{array}$ & $S^{1}$ & $\mathbf{P}^{2}$ & $\begin{array}{l}\text { Risk } \\
\text { Level }\end{array}$ \\
\hline \multirow{3}{*}{$\begin{array}{l}\text { Wrong } \\
\text { actions }\end{array}$} & $\begin{array}{l}\text { Execution of operations } \\
\text { unforeseen in the workload }\end{array}$ & Inadequate & 45-180 days & 3 & 3 & 3 \\
\hline & $\begin{array}{l}\text { Performing operations in order } \\
\text { to use electrical instalations } \\
\text { that are out of order }\end{array}$ & ng & DEATH & 7 & 1 & 3 \\
\hline & Fall & & 45-180 days & 3 & 4 & 3 \\
\hline Omissions & $\begin{array}{l}\text { Omitting operations that } \\
\text { ensure safety at work }\end{array}$ & $\begin{array}{l}\text { Inadequate } \\
\text { training }\end{array}$ & 45-180 days & 3 & 3 & 3 \\
\hline
\end{tabular}

At the same time, it is necessary to plan for the prevention and protection of risk factors, including technical, organizational, hygienic and sanitary measures, actions used to implement the previous measures, as well as the establishment of implementation deadlines and persons responsible for implementing the measures. In general, organizational measures and actions refer to the training of personnel in the field of occupational health and safety, with the exception of electrocution, where the prevention and protection plan is presented in Table 5 .

Table 5. Prevention and protection plan in case of electrocution.

\begin{tabular}{|c|c|c|}
\hline Risk Assessed & Technical Measure & Organizational Measure \\
\hline $\begin{array}{l}\text { Electrocution by direct } \\
\text { touch-uninsulated electrical } \\
\text { installations, open electrical } \\
\text { panels, etc. }\end{array}$ & $\begin{array}{l}\text { Enclosure, insulation of electrical } \\
\text { equipment } \\
\text { Providing personal electric } \\
\text { protective equipment }\end{array}$ & $\begin{array}{l}\text { - The use of the personal electric } \\
\text { protective equipment } \\
\text { Electrical elements that present the risk } \\
\text { of electrocution by direct contact will be } \\
\text { disconnected from the electrical system } \\
\text { Performing work on electrical } \\
\text { installations will be carried out by } \\
\text { authorized electricians from the point of } \\
\text { view of labor protection }\end{array}$ \\
\hline $\begin{array}{l}\text { Electrocution by indirect } \\
\text { touch-putting the electrical } \\
\text { equipment housing under tension } \\
\text { and lack of short-circuit protection }\end{array}$ & $\begin{array}{l}\text { Linking the system earthing } \\
\text { Purchasing equipment with } \\
\text { short-circuit protection (double } \\
\text { insulation, etc.) }\end{array}$ & 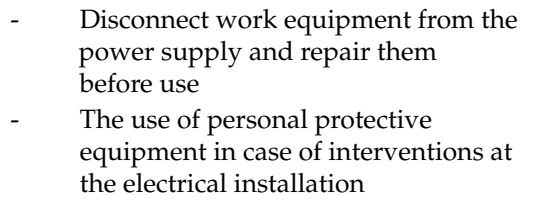 \\
\hline
\end{tabular}




\subsection{Statistical Analysis of the Equipment Failure Incidence}

Maintenance, insurance and managing safety involves controlling problems related to safety issues that may arise in the production processes. In the manufacturing process, the good operation of the machinery is essential to achieving the objectives of production and to obtaining safe, quality products. Thus, in a competitive economy, safety management is a critical component for quality and safe production.

The technological scheme of the water bottling process, illustrating the equipment and machinery used is presented in Figure 1.

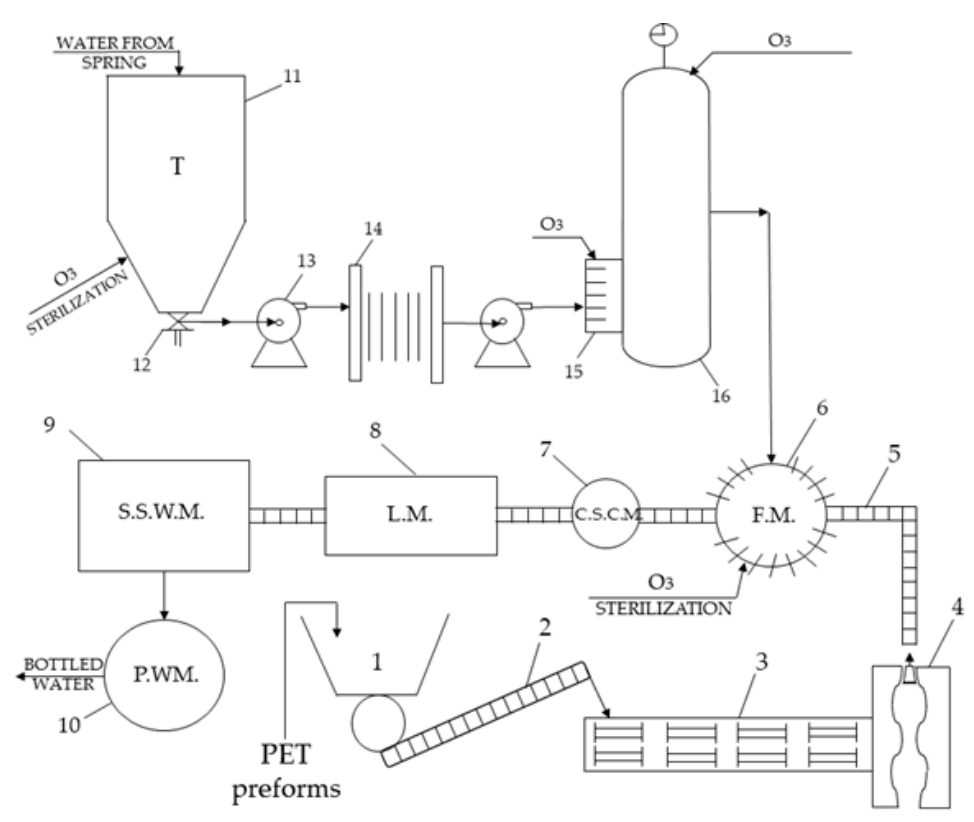

Figure 1. Technological scheme of water bottling process.

Description: 1-tank of PET(polyethylene terephthalate) preforms; 2-screw conveyor; 3 and 4-Blow Molding Machine; 5-Bottle Conveyors; 6-Filling machine; 7-Capping Sealing Corking Machine; 8-Labeling machine; 9-Sealing Shrink Wrapping Machine; 10-Pallets wrapping machine; 11-water tank; 12-solenoid valve; 13-electro pump; 14-plate filter; 15-Ozone generator (Air Tree-Ozone Technology); 16-ozone impregnation. Using the $\chi 2$ ("chi square") test, it was checked whether the calculated probability of the occurrence of defects in the machines within the company differed significantly from the theoretical probability of their presence. So, the chi square $(\chi 2)$ test can be used to evaluate a relationship between two these categorical variables [23,24].

The machines were about 15 years old; they were being used under the same conditions. The question is whether the lower number of malfunctions in some equipment in the process is real and natural. At the same time, the occurrence of more defects in other machines is caused by other factors and is not accidental. All these occured in the context of the annual maintenance of the machinery used in the process. The question is whether there is a need for a higher frequency of interventions related to equipment maintenance.

From the total of 17 defects in the last 3 years, the results for each type of equipment are shown in Table 6.

If, according to the hypothesis, all seven machines from the company that operate simultaneously under the same conditions, the probability that one of them will be out of order is $p=0.143$. The mathematical expectation related to the presence of the number of defects is $\mathrm{M}(n)=2.428$. 
The criterion used for measuring and testing the significance of the deviation of the number of defects from the mathematical expectation of defects is (1):

$$
\chi^{2}=\frac{(F-n \cdot p)^{2}}{n \cdot p}
$$

where: $F$-the frequency of defects, $n$-the sum of incidence of defects.

Table 6. The results of the $\chi 2$ test calculation for equipment occurrences of defects.

\begin{tabular}{ccccccccc}
\hline Machinery & $\begin{array}{c}\text { PET } \\
\text { Bottle } \\
\text { Blowing } \\
\text { Machine }\end{array}$ & $\begin{array}{c}\text { Water } \\
\text { Pump }\end{array}$ & $\begin{array}{c}\text { Filling } \\
\text { Machine }\end{array}$ & $\begin{array}{c}\text { Capping } \\
\text { Sealing } \\
\text { Corking } \\
\text { Machine }\end{array}$ & $\begin{array}{c}\text { Labeling } \\
\text { Machine }\end{array}$ & $\begin{array}{c}\text { Sealing } \\
\text { Shrink } \\
\text { Wrapping } \\
\text { Machine }\end{array}$ & $\begin{array}{c}\text { Wrapping } \\
\text { Machine }\end{array}$ & Total \\
\hline $\begin{array}{c}\text { Number of } \\
\text { defects }\end{array}$ & 1 & 2 & 6 & 4 & 3 & 1 & 0 & 17 \\
\hline $\begin{array}{c}\text { Mathematical } \\
\text { expectation }\end{array}$ & 2.428 & 2.428 & 2.428 & 2.428 & 2.428 & 2.428 & 2.428 & 16.996 \\
\hline$\frac{F-n \times p}{\frac{F-n \times p)^{2}}{n \times p}}$ & -1.428 & -0.428 & 3.572 & 1.572 & 0.572 & -1.428 & -2.428 & 0.004 \\
\hline & 0.839 & 0.075 & 5.255 & 1.017 & 0.134 & 0.839 & 2.428 & 10.590 \\
\hline
\end{tabular}

For $v=7-1=6$ degrees of freedom and the value $\chi^{2}$ computed $=10.590$ we find a significance level ( $\alpha$ or $p$-value) between 0.1 and 0.9 [25]. Therefore, we have no reason to reject the zero hypothesis, and we will admit that the difference between the number of defects is accidental. Therefore, we do not have enough arguments to support the need for a detailed analysis of the causes that produce a large number of defects at the filling machine, staple plugs and at the labeling machine.

\subsection{Safety and Qualitative Investigation of Roua Apusenilor Spring Water}

In Tables 7-9 are presented the organoleptic, physico-chemical and microbiological results of the sample of "Roua Apusenilor" spring water, sourced from the "Lucia Cave", from the village of Sohodol, Alba County.

Table 7. Organoleptic analysis of "Roua Apusenilor" spring water, Sohodol village.

\begin{tabular}{ccc}
\hline Characteristic & Determined & Maximum Admissible Limit \\
\hline Color & No color, without any unusual change & Acceptable to consumers, \\
Taste & Tasteless; without unusual changes & without any unusual changes \\
Smell & Odorless; without unusual changes & \\
\hline
\end{tabular}

Table 8. Results of the physical-chemical analysis of "Roua Apusenilor" spring water.

\begin{tabular}{ccc}
\hline Parameter & Determined Value & Maximum Admissible Value \\
\hline $\mathrm{pH}$ & 7.11 & $6.5 \div 9.5$ \\
Permanganate index, $\mathrm{mgO}_{2} / \mathrm{L}$ & 1.19 & 5.00 \\
Ammonium, $\mathrm{mg} / \mathrm{L}$ & $<0.025$ & 0.5 \\
Nitrite, $\mathrm{mg} / \mathrm{L}$ & $<0.015$ & 0.5 \\
Nitrates, $\mathrm{mg} / \mathrm{L}$ & 3.34 & 50 \\
Turbidity, JTU & 0.3 & 5 \\
General hardness, ${ }^{\circ} \mathrm{dH}$ & 7.93 & Minimum 5.00 \\
Iron, $\mu \mathrm{g} / \mathrm{L}$ & $<10$ & 200 \\
Aluminum, $\mu \mathrm{g} / \mathrm{L}$ & $<0.5$ & 200 \\
Chlorides, $\mathrm{mg} / \mathrm{L}$ & 3.55 & 250 \\
Conductivity, $\mu \mathrm{S} / \mathrm{cm}$ at $20^{\circ} \mathrm{C}$ & 392 & 2500 \\
\hline
\end{tabular}


Table 9. Results of the laboratory microbiological analysis for Lucia spring water.

\begin{tabular}{ccc}
\hline Parameter & Determined Value & Maximum Admissible Value \\
\hline Coliform bacteria & Absent & Absent \\
Escherichia coli & Absent & Absent \\
Enterococcus faecalis & Absent & Absent \\
Total plate count $22^{\circ} \mathrm{C}, \mathrm{CFU} / \mathrm{mL}$ & Absent & 100 \\
Total plate count $37^{\circ} \mathrm{C}, \mathrm{CFU} / \mathrm{mL}$ & Absent & 20 \\
Pseudomonas aeruginosa, $\mathrm{CFU} / 100 \mathrm{~mL}$ & Absent & Absent \\
Clostridium perfringens, $\mathrm{CFU} / 100 \mathrm{~mL}$ & Absent & Absent \\
\hline
\end{tabular}

Tables 7-9 show that the values of the parameters are within the established limits according to the national and European legislation in force. The quality of "Roua Apusenilor" spring water, having as its source the "Lucia Cave" from Sohodol village, is corresponding.

There is an increasing growth of certifications based on the ISO 22000 (food safety management systems) [26]. In the food industry, the implementation and certification of ISO 22000 is currently optional. According to article 5(1) of Regulation (EC) No 852/2004 of the European Parliament and of the Council of 29 April 2004 on the hygiene of foodstuffs requires that all food business operators implement and maintain a procedure based on the HACCP principles. However, there are several external pressures (requirements of the large chain stores, high competition, product visibility on the market, etc.), which lead to the implementation and certification of quality systems and food safety. The reasons for this decision are generally of an internal nature.

According to the ISO 22000 standard, the analysis and the evaluation of the hazards that can appear during all the technological stages at the packaged drinking water plant, "Roua Apusenilor" are shown in Figure 2.

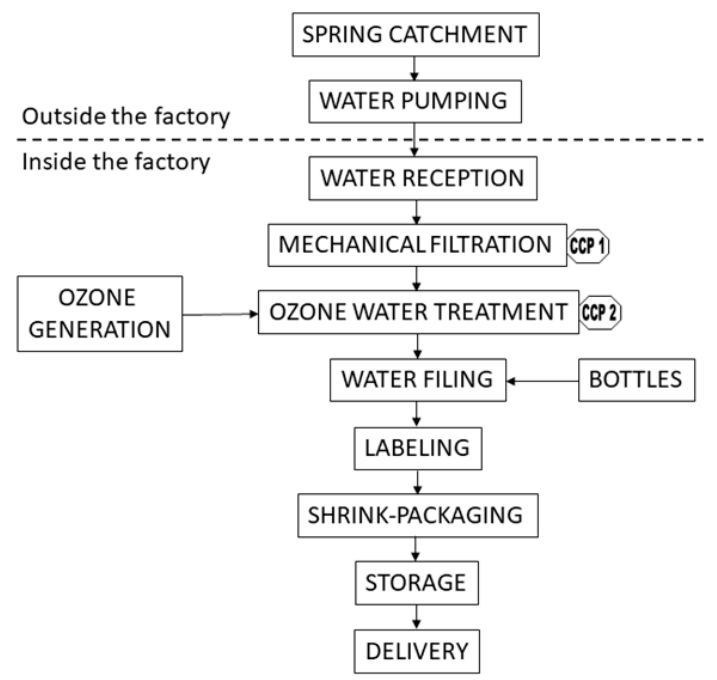

Figure 2. Process flow diagram of water production and bottling.

The risk assessment aims to determine for each safety food hazard whether elimination or reduction to the acceptable level leads to the production of safety food and if it is necessary to control the production in order to keep it within acceptable levels.

The probability of occurrence (frequency) of each identified hazard and their severity (gravity) is analysed, considering that the control measures (or preventive ones) have not achieved their purpose. 
The severity (S) represents the consequences suffered by the consumer as a result of exposure to a contaminant and it is classified into three levels:

- High: fatal consequences, serious illnesses, incurable damages, that occur immediately or after a longer period.

- Medium: Substantial damages and/or illnesses.

- Small: minor injuries and/or diseases, lack of effects or minor effects or consequences that occur only after exposure to high doses, long periods of time.

Probability of occurrence $(\mathrm{P})$ is the probability of having a contaminant due to the lack of control of food protection in the final product at the time of consumption. Probability is determined by measurements or observations during certain specific situations occurring within the company. It is classified into three frequency levels:

- Small: practical impossible to produce or improbable ("theoretical risk").

- Medium: can occur, it happens to occur.

- High: it appears systematically, repeatedly.

Depending on the severity and probability of occurrence, the risk class (RC) is established using the Table 10 [27]:

Table 10. Establish the risk class (RC).

\begin{tabular}{cccc}
\hline Severity (S) & Probability of Occurrence (P) (In the Final Product; At Consumption) \\
\hline High & 3 & 4 & 4 \\
Medium & 2 & 3 & 4 \\
Small & 1 & 2 & 3 \\
\hline
\end{tabular}

The HACCP system approaches the hygienic quality of the food products, being the most efficient means of guaranteeing and controlling the security of them. All types of potential hazards (biological, chemical, physical) that appear in a natural way in the bottled water, either because of the exposure or the contact with a certain environment, or as an effect of a deficiency of the production process, are taken into account.

The analysis of this plan leads to the idea that the mechanical filtration of the spring water and the ozone treatment constitutes $\mathrm{CCPs}$ - critical control points with a physical and biological risk, for the security of the bottled product (Table 11).

Table 11. The analysis and evaluation of the hazards corresponding to the established PCCs for still water.

\begin{tabular}{|c|c|c|c|c|c|c|c|c|c|c|}
\hline Stage & $\begin{array}{l}\text { Type of } \\
\text { Hazard }\end{array}$ & Hazard Description & $S^{1}$ & $\mathbf{P}^{2}$ & RC & $\mathrm{Q}_{1}$ & $\mathrm{Q}_{2}$ & $\mathbf{Q}_{3}$ & $\mathbf{Q}_{4}$ & CCP \\
\hline $\begin{array}{l}\text { Mechanical } \\
\text { filtration }\end{array}$ & Physical & $\begin{array}{l}\text { Impurities (sand, sediment, } \\
\text { sludge, rust or particles in } \\
\text { suspension) }\end{array}$ & Low & High & 3 & yes & yes & - & - & $\mathrm{CCP} 1$ \\
\hline $\begin{array}{l}\text { Ozone } \\
\text { treatment }\end{array}$ & Biological & $\begin{array}{l}\text { Pathogens (E. coli, Clostridium } \\
\text { spp., L. monocytogenes, } \\
\text { Salmonella spp., Staphyloccocus } \\
\text { spp., Y. enterocolitica, C. jejuni, } \\
\text { P. aeruginosa, Shigella spp., } \\
\text { Streptococcus Faecalis, } \\
\text { Legionella spp., etc.), parasites }\end{array}$ & High & Low & 3 & yes & yes & - & - & $\mathrm{CCP} 2$ \\
\hline
\end{tabular}

$\mathrm{S}^{1}$-Severity; $\mathrm{P}^{2}$-Probability of occurrence; $\mathrm{Q}_{1-4}$-Question 1-4. 
Where $Q_{1}, Q_{2}, Q_{3}, Q_{4}$ are the four next questions from the decision tree [28,29]: 1. Do control preventative measure(s) exist? 2. Is the step specifically designed to eliminate or reduce the likely occurrence of a hazard to an acceptable level? 3. Could contamination with identified hazard(s) occur in excess of acceptable level(s) or could these increase to unacceptable levels? 4. Will a subsequent step eliminate the identified hazard(s) or reduce the likely occurrence to an acceptable level?

Also, a process map was created to provide a holistic view of all processes and the relationships between them. Figure 3 shows the process map of the study, which presents the integration between the two ISO 45001 (OHSAS) and ISO 22000 (HACCP) requirements.

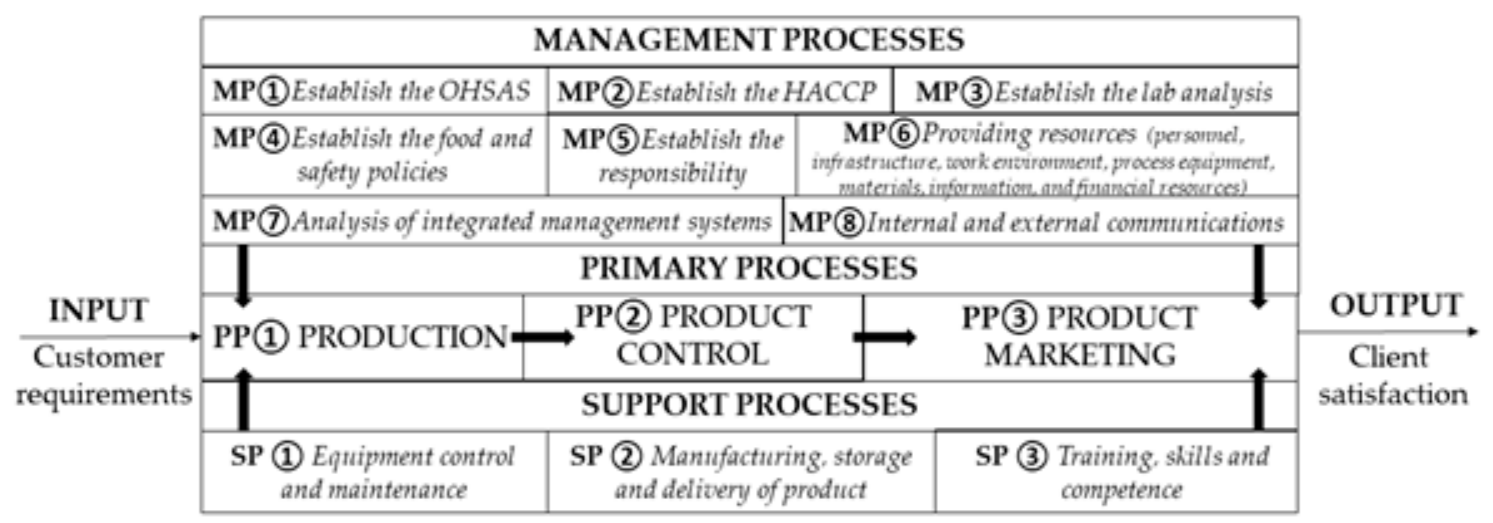

Figure 3. Process map for the integration between food safety and OHS safety in an Integrated Management System.

The process map assists in easier navigation through the processes and enables an understanding of the company's operations without necessarily going into process depth. Presented are the management processes, the main processes and support, which together serve to achieve customer satisfaction.

The Table 12 shows the control measures, critical limits, monitoring procedures, corrective actions and documents and responsibilities for each critical control points. 
Table 12. Control measures, critical limits, monitoring procedures, corrective actions and documents for each CCPs.

\begin{tabular}{|c|c|c|c|c|c|c|c|}
\hline Stage & CCP (No.) & Control Measures & Critical Limits & Monitoring & $\begin{array}{c}\text { Corrective Actions and } \\
\text { Measures }\end{array}$ & Records, Documents & Responsibilities \\
\hline $\begin{array}{l}\text { Mechanical } \\
\text { filtration }\end{array}$ & CCP1 & $\begin{array}{ll}\text { - } & \text { Pressure difference } \\
\text { monitoring, } \Delta p \text { on } \\
\text { filter plate, } \\
\text { - } \quad \text { Pressure } \\
\text { manometer calibration. }\end{array}$ & Maximum. 4 bars & At $1 \mathrm{~h}$ & $\begin{array}{ll}\text { - } & \text { Change filters cartons, } \\
\text { - } & \text { Washing filters, } \\
\text { - } & \text { Filter plate inspection, } \\
\text { - } & \text { Personal training. }\end{array}$ & $\begin{array}{ll}\text { - } & \text { Operational } \\
\text { control sheet, } \\
\text { - } \quad \text { Input water quality } \\
\text { monitoring register. }\end{array}$ & $\begin{array}{ll}- & \text { Operator } \\
- & \text { Quality department } \\
- & \\
& \text { Maintenance manager }\end{array}$ \\
\hline $\begin{array}{l}\text { Ozone } \\
\text { treatment }\end{array}$ & $\mathrm{CCP} 2$ & $\begin{array}{ll}\text { - } & \text { Ozone air } \\
\text { pressure monitoring } \\
\text { - } & \text { Residual } \mathrm{O}_{3} \text { analysis } \\
\text { in product }\end{array}$ & $\begin{array}{c}0.05 \mathrm{mg} / \mathrm{L} \text { Residual } \\
\mathrm{O}_{3}\end{array}$ & Each lot & $\begin{array}{ll}\text { - } & \text { Ozone } \\
\text { generator maintenance, } \\
\text { - } \quad \text { Ozone air } \\
\text { flow regulation } \\
\text { - } \quad \text { Operator training. }\end{array}$ & $\begin{array}{ll}\text { - } & \text { Operational } \\
\text { control sheet, } \\
\text { - } & \text { Quality of final } \\
\text { product } \\
\text { monitoring register }\end{array}$ & $\begin{array}{ll}- & \text { Operator } \\
- & \text { Quality department } \\
- & \\
& \text { Maintenance manager }\end{array}$ \\
\hline
\end{tabular}




\section{Discussion}

Groundwater resources from alpine and mountainous karst aquifers play an important role in public water supply in many areas throughout the world [30]. The quality control of natural spring water is of interest and is a priority action for government authorities. Raw water plays an essential role for drinking purposes and for other sanitary uses and industrial processes [31]. A decrease in the number of springs or the drop in their discharge, as well as disadvantageous changes in chemistry and quality of spring waters, indicate degradation of the environment [32].

In an industrialized country, located in the temperate-continental climate, about $80 \%$ of the used water returns to the natural circuit as wastewater. Every day, two million tons of wastewater are discharged unpurified into the water sources, globally and, according to the National Institute of Hydrology and Water Management, few of the major cities of Romania have wastewater treatment plants conforming to European requirements [9]. The average of the natural reserve of water in Romania is estimated at about $1700 \mathrm{~m}^{3} /$ inhabitant/year, compared to about $4200 \mathrm{~m}^{3} /$ inhabitant/year in France [33]. The water supply situation in Romania shows that the population served by the public water supply system accounted for $65.2 \%$ of the total population of Romania in 2016, the share being only $30 \%$ in rural areas, according to a press release of the National Institute of Statistics [34].

As Romania is rich in hydrographic resources, which are made available to people in the natural environment through springs, thus the safety and security of drinking water must be approached with total responsibility.

From the economic point of view, spring waters represent a free good, enjoyed and accessed by the inhabitants of the surrounding area, but the capture of these springs, the verification of the water quality, its certification, the bottling process and its offering for consumption through marketing transform this free good into an economic good, which is subject to the economic laws governing the market. Testing the water quality of untreated groundwater sources (spring, wells, drilling) helps people understand the existence of water quality problems, and the measures that can be taken to treat water and manage water supply.

In order to determine our areas of interest we have used official databases owned by the Romanian Ministry of Health, that control public water sources (including underground water). In 2017, 132 public water sources declared by the municipalities in Alba County were monitored. According to Directive 98/83/EC [7], water quality indicators have been analyzed. The results show that out of 132 samples, 58 are potable and 74 are unsuitable for consumption. From the analysis of the obtained results, it was found that most investigated underground water sources (wells and springs) do not meet the standards required for drinking water. It is observed that the mountain region (Câmpeni area) is the closest to the standard of $72 \%$ potable water in Alba County. Here the water quality is superior when compared to the low region.

Also, countries from all over the world, have been involved in creating instruments capable of implementing the safety and security objectives, or in creating the framework to identify, control and decrease the risks associated with health and safety within the workplace. Thus, standards such as the ISO 45001 and ISO 22000 are standards of security, quality and especially food safety, designed to allow the hazard identification, risk assessment and determination of controls in a unitary approach. These standards apply to all industries—-the ISO 45001 and the ISO 22000 — to all stages of food industry.

Differences between ISO 45001 and OHSAS 18001 show that the ISO 45001 follows the structure of the approach that is being applied to other ISO management system standards, such as the ISO 9001 (quality management system standard) and the ISO 14001 (environmental management system standard), following Plan-Do-Check-Act (PDCA) approach. In developing the ISO 45001 standard, consideration has been given to the content of other standards, such as the International Labour Organisation's "ILO -OSH Guidelines", as well as to the ILO's International Labour standards and conventions (ILSs). 
Implementation of food safety management system according to ISO 22000 implies in broad terms: the establishment of product requirements, production conditions, personnel management, external regulatory requirements, implementation and maintenance of procedure for potential emergency situations and accidents management, which can influence food safety, identification and assessment of all biological, chemical and physical hazards, and relevant control measures upon their occurrence for each kind of product/process using an HACCP plan with prerequisite programs. The standard is based on Good Manufacturing Practices (GMP), Good Hygiene Practices (GHP), HACCP and quality management (ISO 9001).

Management of OHS risks is a crucial component in the legislative landscape of most countries and in any business $[35,36]$. Existing methodologies for reducing harm are primarily based on the risk methodology [37], namely the reduction of consequence or the likelihood of harm.

OHSAS and HACCP share the same goal of safety production for safe food products. The focus of OHSAS is on the risk management process, which involves risk analysis, risk assessment and risk control practices for all the factors that surround food, whereas the focus of HACCP is on controlling intrinsic hazards to food and on the environment surrounding the products to prevent contamination. Together they provide the organizational base for applying the correct methods and procedures to ensure and verify the safety of production and of the product. These approaches also provide records (data collection through direct observation onsite and through dialog with the workers, checklists, statistical analysis) which demonstrate that safety measures have been considered as planned. The resulting integrated system has a better chance of controlling all the hazards. According to Figure 3, the obtained results were analyzed qualitatively in order to determinate of the hazards in the company. In practice, the analysis results of OHS for all workplaces within the organization were corroborated with the results for evaluation of the hazards that can appear during all the technological stages. They show that the measures proposed by the HACCP team, whose main goal is to promote food safety, are also preventive, namely, to avoid verified hazardous situations, thus reducing the number of risks that people who work there are under. HACCP intervention is shown in almost all situations of danger, apart from the ones that cause ergonomic hazards and risks caused by noise exposure. It was found that it is essentially at the basis of their system (prerequisites) that HACCP provides the greatest contribution to the prevention of occupational risks. On the other hand, one can also see that the prevention and control measures proposed by OHS services represent a strong contribution to the effectiveness of the HACCP system of food hygiene and safety.

The benefits and limitations of the study are based on practical observations and experiences, being integrated into the quality management system of the requirements of the two standards: ISO 45001 and ISO 22000; securing workplace safety, as well as product safety, reducing manufacturing costs, controlling processes. The ongoing research in this field aims to develop an ideal system which quantifies the impact of the implementation of the two standards. Continuous research is dedicated to this topic, based on the understanding of the benefits and limitations. However, the implementation of the standards helps to achieve the goals but require effort.

\section{Conclusions}

The study constitutes an investigation regarding the risk of injury and occupational disease assessment for all workplaces within the organization according to the ISO 45001 standard. The study justifies the importance of elaboration on a plan for the prevention and protection of risk factors that includes technical, organizational, hygienic and sanitary measures, actions used to implement the previous measures, as well as the establishment of implementation deadlines and persons responsible for implementing the measures. The employees working in the water bottling industry, in Monopolis SA Company, are exposed to hazards and risks. The ergonomics, physical, psychological risks are minor but are likely to happen. Also, the study found that the organoleptic, physico-chemical and microbiological parameters determined were within the permissible limits in the water sources examined. These results indicate a good hygienic quality of water source—-the "Lucia Cave", Sohodol village. The statistical 
analysis shows that the difference between the incidence of occurrence of defects at different machines from the factory is accidental. The causes that lead to equipment defections are purely accidental and require further investigation. According to the ISO 22000 requirements, the frequency of machines maintenance actions can be increased, without any association between the variables under analysis. The implementation of an efficient management system for the security of the food products (ISO 22000) ensures the optimal conditions of monitoring and controlling within water processing, and at the same time preventing the risk of its contamination. The HACCP principles were applied, and the critical control points identified include filtration and ozone water treatment. It was observed, that the activities carried out in the company became more efficient and improved by applying the framework of the process map that integrated the HACCP and OHS management systems.

The review of the case helped us better understand the benefits and limitations of the ISO 45001 and ISO 22000 standard implementation. Future studies should also focus on assessing whether the requirements of other standards such as ISO 14000 and ISO 9001, help with controlling the safety issues in the water bottling processes.

Author Contributions: Conceptualization, M.P.; Formal analysis, A.S.; Investigation, I.G.; Methodology, I.G.; Supervision, M.P.; Visualization, A.S.

Funding: This research received no external funding.

Conflicts of Interest: The authors declare no conflict of interest.

\section{References}

1. Demeritt, D.; Rothstein, H.; Beaussier, A.L. Mobilizing risk: Explaining policy transfer in food and occupational safety regulation in the UK. Environ. Plan. A 2015, 47, 373-391. [CrossRef]

2. De Oliveira Matias, J.C.; Fonseca, J.M.J.; Barata, I.G.; Proença Brojo, F.M.R. HACCP and OHS: Can each one help improve the other in the catering sector? Food Control 2013, 30, 240-250. [CrossRef]

3. Oluoch, I.; Njogu, P.; Ndeda, J.O.H. Effects of Occupational Safety and Health Hazards' Exposure on Work Environment in the Water Service Industry within Kisumu County-Kenya. IOSR J. Environ. Sci. Toxicol. Food Technol. 2017, 11, 46-51. [CrossRef]

4. Negrea, A.; Muntean, C.; Ciopec, M.; Lupa, L.; Negrea, P. Removal of Arsenic from Underground Water to obtain Drinking Water. Chem. Bull. "POLITEHNICA" Univ. (Timisoara) 2009, 54, 82-84.

5. Calisevici, M.; Perju, D.; Lysandrou, M.; Dumitrel, G.A.; Glevitzky, M. Determination of anion and cation contents in Cyprus drinking waters by HPIC method. J. Food Agric. Environ. 2011, 9, 65-68.

6. Law No. 458/2002 Regarding the Quality of Drinking Water. In The Official Journal of Romania; Government of Romania: Bucharest, Romania, 2002.

7. Council Directive 98/83/EC on the Quality of Water Intended for Human Consumption, L 330. In Official Journal of the European Union; The European Parliament and the Council of the European Union: Brussels, Belgium, 1998; pp. 32-54.

8. Todoran, A.; Vica, M.; Glevitzky, M.; Dumitrel, G.A.; Popa, M. Water Environmental Situation of Wells in Galda de Jos Village, Romania: Microbiological control. Chem. Bull. "POLITEHNICA" Univ. (Timisoara) 2010, 55, 95-98.

9. Stomff, S. Ziua Mondiala a Apei. Rev. Standardizarea 2009, Martie, 20-23. (In Romanian)

10. Brânzei, G.M.; Lupşa, I.R.; Zora, M.; Negrea, A.; Iovi, A.; Bragea, M. Contribution to the Knowledge of Iron Contains in Water from West Zone of Romania. Chem. Bull. "POLITEHNICA" Univ. (Timişoara) 2008, 53, 226-229.

11. Directive 2006/42/EC on Machinery, and Amending Directive 95/16/EC. In Official Journal of the European Union; The European Parliament and the Council of the European Union: Brussels, Belgium, 2006.

12. Fan, Q.; Fan, H.Q. Reliability Analysis and Failure Prediction of Construction Equipment with Time Series Models. J. Adv. Manag. Sci. 2015, 3, 203-210. [CrossRef]

13. International Organization for Standardization. ISO 45001 Occupational Health and Safety Management Systems_Requirements; International Organization for Standardization: Geneva, Switzerland, 2018.

14. International Organization for Standardization. ISO 22000 Food Safety Management Systems-Requirements for any Organization in the Food Chain; International Organization for Standardization: Geneva, Switzerland, 2018. 
15. Occupational Health and Safety Assessment Series. BS OHSAS 18001 Occupational Health and Safety Management Systems—Requirements; British Standards Institution: London, UK, 2007.

16. International Organization for Standardization. ISO 9001 Quality Management Systems_Requirements; International Organization for Standardization: Geneva, Switzerland, 2015.

17. International Organization for Standardization. ISO 14001 Environmental Management Systems_Requirements with Guidance for Use; International Organization for Standardization: Geneva, Switzerland, 2015.

18. Păunescu, C.; Argatu, R.; Lungu, M. Implementarea standardului ISO 22000 în companiile românești: Motivații, dificultăți și beneficii cheie. Amfiteatru Econ. 2018, 20, 31-47.

19. Regulation (EC) No. 852/2004 on the Hygiene of Foodstuffs, L 139. In Official Journal of the European Union; The European Parliament and the Council of the European Union: Brussels, Belgium, 2004; pp. 1-54.

20. Damikouka, I.; Katsiri, A.; Tzia, C. Application of HACCP principles in drinking water treatment. Desalination 2007, 210, 138-145. [CrossRef]

21. Anghel, G.; Anghel, D. Alba un județ in inima țări; Unirea Pres: Alba Iulia, Romania, 2006. (In Romanian)

22. EU General Risk Assessment Methodology (Action 5 of Multi-Annual Action Plan for the Surveillance of Products in the EU (COM 76); European Commission-Directorate-General for Internal Market, Industry, Entrepreneurship: Brussels, Belgium, 2013.

23. Kogălniceanu, R. Utilizarea testului $\chi 2$ în arheologie. Studiu de caz-Necropola neolitică de la cernica. Arheologia Moldovei 2005, 28, 265-302. (In Romanian)

24. McHugh, M.L. The Chi-Square Test of Independence. Biochem. Medica 2013, 23, 143-149. [CrossRef]

25. Gluck, A. Metode Matematice în Industria Chimică; Tehică: Bucuresti, Romania, 1971; pp. 48-50.

26. Maiorescu, I. The Role of Marketing in the Real ISO 9001:2000 Quality Management System. Amfiteatru Econ. 2008, 10, 126-129.

27. National Good Practice Guide for Food Safety_HACCP Food Safety System; Uranus: Bucuresti, Romania, 2007; pp. 122-123.

28. Marriott, N.G.; Gravani, R.B. Principles of Food Sanitation, 5th ed.; Springer Scientific: New York, NY, USA, 2005; p. 170.

29. Schmidt, R.H.; Rodrick, G.E. Food Safety Handbook; John Wiley \& Sons, Inc.: Hoboken, NJ, USA, 2003; pp. 276-278.

30. Farnleitner, A.H.; Wilhartitz, I.; Ryzinska, A.G.; Kirschner, K.T.; Stadler, H.; Burtscher, M.M.; Hornek, R.; Szewzyk, U.; Herndl, G.; Mach, R.L. Bacterial dynamics in spring water of two contrasting alpine karst aquifers indicate autochthounous microbial endokarst communities. Environ. Microbiol. 2005, 7, 1248-1259. [CrossRef]

31. Winquist, F.; Olsson, J.; Eriksson, M. Multicomponent analysis of drinking water by a voltammetric electronic tongue. Anal. Chim. Acta 2011, 683, 192-197. [CrossRef]

32. Michalik, A. The Use of Chemical and Cluster Analysis for Studying Spring Water Quality in Świętokrzyski National Park. Pol. J. Environ. Stud. 2008, 17, 357-362.

33. Chiriac, D.; Humă, C.; Tudor, C. Impactul socio-economic al apei asupra calităţii vieții populaţiei din România. Calitatea Vietii. 2001, 12, 95-116.

34. National Institute of Statistics. 2016 Romanian Statistical Yearbook. Available online: http://www.insse.ro/ (accessed on 2 April 2019).

35. Kaassis, B.; Badri, A. Development of a Preliminary Model for Evaluating Occupational Health and Safety Risk Management Maturity in Small and Medium-Sized Enterprises. Safety 2018, 4, 5. [CrossRef]

36. Ji, Z.; Pons, D.; Pearse, J. Why Do Workers Take Safety Risks?-A Conceptual Model for the Motivation Underpinning Perverse Agency. Safety 2018, 4, 24. [CrossRef]

37. Rigas, F.; Konstandinidou, M.; Centola, P.; Reggio, G.T. Safety analysis and risk assessment in a new pesticide production line. J. Loss Prev. Process Ind. 2003, 16, 103-109. [CrossRef]

(C) 2019 by the authors. Licensee MDPI, Basel, Switzerland. This article is an open access article distributed under the terms and conditions of the Creative Commons Attribution (CC BY) license (http://creativecommons.org/licenses/by/4.0/). 